\title{
Econometric Analysis of Labour Demand in Textiles, Clothing and Footwear Manufacturing Sector in South Africa: 1990 - 2011 \\ Tafadzwa R Chikwanha
}

\author{
Department of Economics, University of Fort Hare, Email: chikwanhat@gmail.com
}

Ireen Choga

School of Economic \& Decision Sciences, North West University, South Africa.

(Corresponding Author) Email: Ireen.Choga@nwu.ac.za

\section{Andrew Maredza}

School of Economic \& Decision Sciences, North West University, South Africa. Email: Andrew.Maredza@nwu.ac.za

\section{Associate Professor Nehemiah Mavetera}

School of Economic \& Decision Sciences, North West University, South Africa. Email: Nehemiah.mavetera@nwu.ac.za

\section{Dr Costa Hofisi}

School of Management Sciences, North West University, South Africa. Email: costa.hofisi@nwu.ac.za

Doi:10.5901/mjss.2013.v4n14p227

\section{Abstract}

South Africa in its quest for socio-economic improvement still faces the problem of persistent high rate of unemployment. Unemployment in South Africa is very intricate and therefore makes it a complex challenge to tackle for policy makers. Differing rates of unemployment do exist in different sectors of the economy. Some sectors are facing employment growth while others are declining. This study examines the possible major determinants of labour demand (employment) in the Textiles, clothing and footwear manufacturing sector in South Africa. The study is based on quarterly time series data from 1990 to 2011. The Johansen (1991) model is used to examine these trends. The model is an error correction model imposed upon a vector autoregressive model. The results obtained showed that wages and imports both have negative relationships with the demand for workers. Based on these two important results, the study recommended the introduction of a sector-based wage subsidy. The wage structure in South Africa is a perpetually problematic factor of the labour market and therefore is also a significant determinant in the viability of business and investment. Secondly, the import structure on textiles, clothing and footwear is not clearly and thoroughly defined. A complete restructuring of import tariffs on the entire sector is also herein suggested.

Keywords: Labour demand, Unemployment, Vector error correction, Textiles clothing and footwear sector.

\section{Introduction}

The South African economy in the decade preceding 1994 was to large proportions depressed (and in other instances negative) but improved momentously between the periods 1994 and 2004, averaging 2.8\% annual growth rate. The annual real Gross Domestic Product (GDP) reached peak growth rates of $5.1 \%$ in 2005 and $5.2 \%$ in 2006 and then slowed down for the succeeding years (SEDA, 2008). Various suggestions have been brought up to explain the cause of the growth. Improvements in human capital and technology have been raised as some valid reasons. The question however beckons on what can be the real determinant of long term economic growth in South Africa.

South Africa has persistently faced the problem of severe unemployment, especially among the black population 
as stipulated in the country's demographic groups. The formal unemployment rates by race in South Africa were 41.2\%, 23.3\%, 17.1\% and 6.3\% among Africans, coloureds, Indians and Whites respectively by 1994 (StatsSA, 2009). Unemployment rates declined to $29 \%, 22.6 \%, 11.7 \%$, and $5.9 \%$ by 2011 among the same racial groups respectively (StatsSA, 2011). Members of the African and Coloured races comprised the largely unskilled portion of the labour force. Albeit the marked decline in unemployment rates, the racial and skills based disparities remain considerably large.

Despite its size, the manufacturing sector typically in developing economies is a major source of formal sector employment in general (Roberts and Skoufias, 1997). Regardless of structural modifications, manufacturing remains an important sector in the South African economy. The sector contributed on average around 18\% of the annual GDP from 2008, making it the second largest contributor just behind the services industry which contributed an average of $21 \%$. The sector provides a locus for inducing growth of other industries, services and achieving specific outcomes such as employment creation and targeted economic empowerment. South Africa's New Growth Path aims to create five million jobs by 2020 and bring the unemployment rate to 15\% (UNISA, 2011). The manufacturing sector has been identified as one of the "Six Priority Areas" along with infrastructural development, agriculture, mining, the green economy and tourism. The Formal unemployment rate in the country stands at $23.9 \%$ thus making the demand for labour in the manufacturing sector (largely unskilled labour) relatively elastic.

The information technology, motor vehicle (disregarding the decline caused by the 2007-2009 recession) and food manufacturing industries have been on the rise while massive decline in textiles, clothing and footwear ${ }^{1}$ (TCF from then on) manufacturing industry has been observed. Industry based employment (thus demand for labour) has declined from peaks of over 300000 in 1990 to roughly over 60000 in 2010 (DTI, 2011). The TCF manufacturing has been declining in terms of average growth in real output with 2.8\% between 1996 and 2005 and employment growth of -1.5\% (SEDA, 2008). Between the recessionary 2008 and 2010 the industry experienced year on year employment changes of $-10,4 \%$, $-9,2 \%$ and $-0,5 \%$ respectively (StatsSA,2011).

The South African TCF manufacturing industry has been and remains a very significant source of employment, particularly for women in South Africa. In the traditional geographical concentrations, the industry has existed for many decades; it provides a significant proportion of employment (Jauch and Traub-Merz, 2006). The demand for labour is said to be derived demand, in that workers are hired for the contribution they can make toward producing some good or service (Ehrenberg and Smith, 2006). The rise in unemployment, coupled with robust economic upsurge, has elicited allegations of "jobless growth" amongst policy makers and labour unions. South Africa has for years been experiencing jobless growth and massive structural unemployment. The country has grown economically by improving technology, information communication systems and trade openness. Growth in these areas has resulted in a counter effect that has seen a massive substitution of labour in favour of other means of production. The liberalization of trade has also resulted in vast influxes of cheaper produced commodities from other countries thus creating long term and persistent bottlenecks in demand for locally produced commodities. On the other hand, arguments have arisen that tighter labour legislation to protect the interests of the marginalized have had unintended impacts on the willingness of firms to absorb more labour (IMF, 2009). A wide range of government and private sector activities affect labour market outcomes by altering employers' demand for workers. Demand policies such as minimum wages, requirements for non wage amenities and employer taxes all alter the cost of hiring workers and can thus impact the manufacturing sector (Roberts and Skoufias, 1997).

As a result of the above phenomena, unprecedented job losses have been experienced in the TCF manufacturing sector in the country. The decline in the sector, which has a long history of employing unskilled workers, has contributed to poverty and unemployment growth among targeted demographic groups in the country. Thousands of jobs have been lost over the past ten years and 35500 were lost by 2002. Twenty four firms have closed down since July 2002 while several others are threatened with closure (DA, 2009). According to the DTI (2011), employment in the TCF manufacturing sector declined by between 50000 and 60000 workers for the two and a half years preceding 2006 and a further 1000 per month since. The TCF manufacturing sector in the country has been largely a source of employment for unskilled persons. With such marked decline in the demand for labour in the sector, poverty, inequality, social distress and welfare dependence have been exacerbated.

A diversity of measures has been deliberated by the government and many stakeholders that would be fundamentally powerful in reducing the problem. Government noted specific interventions that could begin to impact the demand for unskilled labour such as: import restrictions, fixed exchange rate systems that would favour demand for South African commodities, double-tier labour markets, wage subsidies and deregulation of labour markets (Bhorat and

${ }^{1}$ TCF in this study falls under Standard Industrial Classification (SIC) codes 311-317 but excludes leather manufacturing SIC 316. 
Jacobs, 2010). Despite the aforementioned tactics being implemented, the clothing and textile manufacturing sector continues to decline and with it the demand for workers.

Taking into observation the various economic policies set up by government at both macroeconomic and industrial level to curb the incessant unemployment problem in the TCF sector, it is vital to determine the extent to which these policies have either succeeded or come short. The general consensus among the relevant authorities is that the policies implemented thus far have had negligible remedy on the problem at hand.

The study is further disaggregated into five other sections. Section 2, shows a miniature overview of the prevailing patterns in employment in the South African TCF sectors over the period 1990 to 2011. The third section presents a brief outline of theoretical and empirical literature upon which the study is based and formulated. Section 4 illustrates the methodology and data sources utilised in the study. The fifth section shows the estimation of the econometric model and illustrates the results obtained thereof. The final section presents the conclusions and the major policy recommendations.

\section{The TCF Manufacturing Sector in South Africa (1990-2011)}

The general trend in the TCF sector employment has been a declining one. The South African TCF sector comprises largely semi-skilled and unskilled workers. 79 percent, 83 percent and 91 percent of employees in the textiles, clothing and footwear sectors respectively are semi-skilled and unskilled (Roberts and Thoburn, 2004). The period from 19911993 saw a rapid decline in employment levels from around 300000 workers to 250000 and slightly below 250000 respectively. Figure 1 illustrates these declines as about $7 \%, 13 \%$ and $1 \%$ respectively in the same period. This was the first perpetual drop in employment experienced in the sector for the 1990's period. From 1996-2001, perennial and unprecedented declines in employment were experienced. By the year 2001, the number of workers in the TCF manufacturing sector had fallen by $54.2 \%$ from the 1995 level (DTI, 2012).The general rise in remuneration paid out to workers was a consequence of increase in unionism and bargaining power of employees. This phenomenon persisted in this period despite the marked declining trend in the number of workers employed during the same period. Between 1997 and 2001 marked declines occurred in the wage structures. In 2001 the lowest wages were paid out for the entire period. The declining pattern of wages was consistent with a similar trend that occurred in employment during the period 19952001.

Figure 1: Employment and wage trends in TCF manufacturing in South Africa (1990 to 2011)

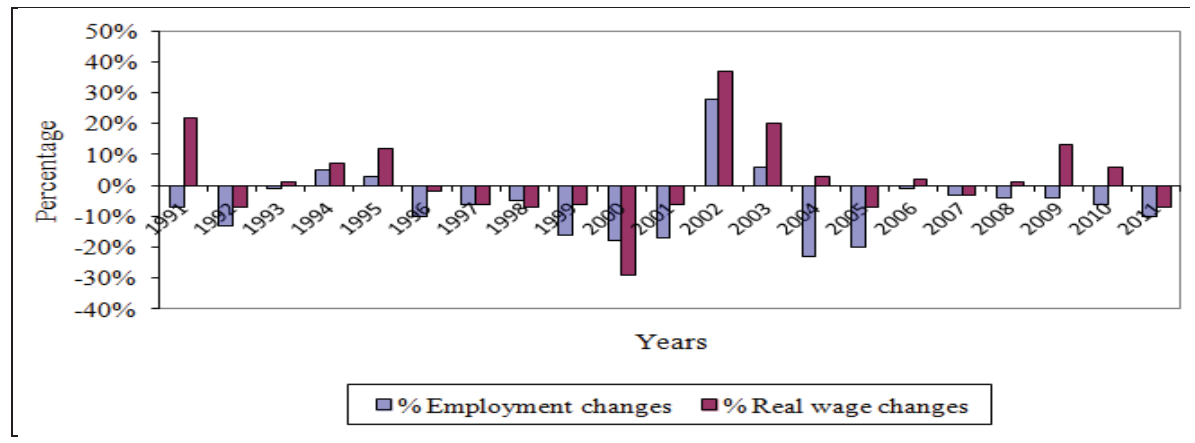

Source: Own graph (Department of Trade and Industry, 2012)

\section{A Review of Supporting Literature}

Several economic theories are used in conjunction as the underlying bases for this study. The relevant theories include the Classical market model, the Marginal revenue productivity (MRP) theory of labour demand, the long run theory of labour demand and the Union wages model. The above models all have attributes and postulations that are relevant to South African labour markets. The Classical model advocates the importance of factor cost (wages) in determining the equilibrium level of employment while the MRP theory emphasises the concept of "derived demand" which suggests that workers are hired by firms because of the need to produce a commodity demanded by consumers. According to this short run model, output can only be influenced by manipulating the level of labour hired by the firm. The long run theory 
not only includes the concept of output affecting labour demand, but suggests the impact of wages relative to cost of capital as strong determinants of employment since it can be substituted for capital in the long run; thus the scale and substitution effects (McConnell, Brue and MacPherson, 2009; Barker, 2007). The Union wages model argues that the existence of labour unions and bargaining council has strong upward thrusts on wages therefore diminishes the demand for workers (Lewis, 1963; Ehrenberg and Smith, 2006).

The concept of labour demand in the manufacturing sector has been studied by various researchers. The studies have focused on varying determinants of labour demand in the different sectors in a lot of countries. The studies conducted implemented different econometric techniques and produced varying results. In developed economies, studies have been conducted by Freeman and Medoff (1982), Hamermesh (1993), Berman, Bound and Griliches (1994), Bruno, Falzoni and Helg (2005) and Onaran (2008). Literature on the subject in less developed and developing economies is provided by Teal (1995), Roberts and Skoufias (1997), Heshmati and Ncube (2003) and Alessandrini (2009). South Africa, contrary to more developed countries does not have as much literature on labour demand in the manufacturing sector. This is not to say it is non-existent. Various studies have been conducted by Moolman (2003), Bhorat (2003) and Behar (2004) in this field. This short review on the models informs the choice of the methodology used in this study.

\section{Methodology Used in the Study}

A vector auto-regressive model (VAR) was identified as the viable model and was therefore implemented for the purpose of estimating the respective impacts of the determinants of labour demand in the TCF sector in South Africa. The time series data to be utilised in the econometric model was primarily subjected to unit root tests using the Dickey Fuller and the Augmented-Dickey Fuller tests. To test for cointegration, the Johansen $(1991,1995)$ cointegration method is utilised. A vector error correction model (VECM) is utilised to estimate the long run equation and the existence of error correction. Diagnostic tests were conducted to check and validate the stochastic properties of the model. The Durbin-Watson (DW) model was employed as the test for autocorrelation. White's test was used to test for heteroscedasticity in the residuals. To test for normality in the distribution of residuals, the Jarque-Bera (JB) test was used.

Tracking the reactions of the system to shocks in the variables and decomposing forecast error variances in VAR are benchmark devices for economic analysis (Lutkepohl, 1990). In this study, they show the extent to which labour demand reacts to disturbances in itself and other variables. Proportions of the forecast error variances of the variables accounted for by innovations in other variables are shown. The tests however, ignore the impact of variations in values of the variables in the system on other variables and the durations of the effect (Brooks, 2008). To an extent, variance decompositions and impulse responses offer the same information (Brooks, 2002).

\section{Model Specification}

To estimate the impact of different variables on labour demand in the clothing and textile manufacturing sector, the study modifies the econometric model by Heshmati and Ncube (2003), in their study, "An Econometric analysis of employment in Zimbabwe manufacturing industry empirical model".

$$
L=f(y, w, k, t, \alpha) \text {. }
$$

Where $L$ is the level of employment (measured as number of persons) used in production of a certain level of output $\mathrm{y}, \mathrm{k}$ is cost of capital, $\mathrm{t}$ are time varying trends and $\mathrm{a}$ is a vector of unknown parameters to be estimated.

From the above equation, the following equation was modelled with variables adjusted to suit the clothing and textile sector in South Africa.

$$
L_{t}=\beta_{0}+\beta_{1} I M P_{t}+\beta_{2} O U T_{t}+\beta_{3} W I R_{t}+\mu_{t}
$$

The variables are converted into their logarithmic form to capture the changes in the data and coefficients of elasticity rather than the absolute trends. The model assumes the structure below:

$$
\operatorname{LnL}_{t}=\beta_{0}+\beta_{1} L n I M P_{t}+\beta_{2} L n O U T_{t}+\beta_{3} L n W I R_{t}+\mu_{t}
$$

Where:

$L n L_{t} \quad=\log$ quantity of workers demanded (actual employment)

LnIMP $\quad=\log$ value of imports of textiles, clothing and footwear

LnOUT $_{t} \quad=\log$ real value of textile manufacturing output

$L_{n W I R} \quad=\log$ of wage to interest ratio. The wage value is actually the mean wage converted to real terms while the interest rate is the Prime lending rate (proxy for cost of capital) converted to real terms year 2000 is used as the base year. 


$$
\begin{aligned}
& \text { Bo } \quad=\text { intercept term } \\
& \beta_{1} \ldots \beta_{3}=\text { slope parameters and } \\
& \mu_{t} \quad=\text { error term. }
\end{aligned}
$$

Data utilised in the study was collected and computed from the Statistics South Africa (StatSA), South African Department of Trade and Industry (DTI) and the Central Intelligence Agency (CIA) statistical databases. The data used in this study is time series quarterly data for the period 1990 to 2011.

The Dickey-Fuller (1979) and Augmented Dickey-Fuller (1984) unit stationarity checks were used to test for the presence of unit roots in the series. Several reasons exist for the importance of the concept of stationarity and why it is important that variables that are nonstationary be treated differently from stationary ones. Since the whole value in the auto regressive from the prior period is carried forward to the present period, values of random walk never decline. The incessant accumulation of errors generates a problem that nonstationary time series will incline toward an infinite variance (Salvatore and Reagle, 2002). This would have led to spurious or nonsense regressions being generated. Table 1 shows the results of the unit root tests. Both the Dickey-Fuller and the Augmented Dickey-Fuller results suggest the existence of unit roots in the level series at $1 \%$ significance level (s.l). At that similar $1 \%$ s.l the series proved to be

\begin{tabular}{|c|c|c|c|c|c|}
\hline Test/Series & & L & IMP & OUT & WIR \\
\hline \multirow[b]{2}{*}{ DF } & Level & -2.654 & -1.308 & -1.107 & -2.760 \\
\hline & $1^{\text {st }}$ Difference & $-8.721^{\star \star \star}$ & $-9.279^{\star \star \star}$ & $-10.285^{\star \star \star}$ & $-3.090^{* *}$ \\
\hline \multirow{2}{*}{ ADF } & Level & -2.845 & -0.251 & -0.884 & -2.988 \\
\hline & $1^{\text {st }}$ Difference & $-8.755^{\star \star \star}$ & $-9.266^{\star \star \star}$ & $-10.809^{\star \star \star}$ & $-5.609^{* \star \star}$ \\
\hline
\end{tabular}
stationary when differenced except for wage to interest ratio which was stationary at $5 \%$ s.l.

Table 1: Stationarity Tests results

\section{Main Findings}

The cointegration technique was applied to the labour demand model. The appeal of cointegration analysis is that it basically provides a useful formal technique for estimating (also testing and modeling) long run economic relationships in time series data.Gujarati and Porter (2010) state that two or more time series which are co-integrated imply the existence of a long run relationship or equilibrium relationship between them. To implement the framework, the correlations among the variables are tested first.

Table 2: Pair-wise correlations

\begin{tabular}{|c|c|c|c|c|}
\hline & L & IMP & OUT & WIR \\
\hline L & 1 & -0.11854 & 0.169859 & -0.064925 \\
\hline IMP & -0.011854 & 1 & -0.009528 & -0.027470 \\
\hline OUT & 0.169859 & -0.009528 & 1 & -0.026298 \\
\hline WIR & -0.064925 & -0.027470 & -0.26298 & 1 \\
\hline
\end{tabular}

Table 2 shows the correlations among the variables utilised in the study. It is seen that although the variables are in different ways correlated, correlation is however very weak. The demand for labour $(L)$ is positively correlated to textile manufacturing output. This is consistent with the basic underlying economic concept. The increase in output is assumed to increase the employment of labour. The correlation between demand for labour and imports is as expected, negative. Imports are expected to act as substitutes for the demand for locally produced commodities, thus a weakness in the demand for workers should arise if imports rise. The weak negative correlation between wage to interest ratio and demand for labour is consistent with economic theory since we assume a rise in wages would trigger reduced demand for workers and vice versa. The weak correlation though, is not entirely explained by theory since theory assumes wages as some of the biggest determinants of demand for workers. The second step of the Johansen $(1991,1995)$ model is to identify the most appropriate lag length to utilise in the model. 
Table 3: Lag order selection criteria

\begin{tabular}{|c|c|c|c|c|c|c|}
\hline Lag & LogL & LR & FPE & AIC & SC & HQ \\
\hline 0 & 16.82392 & NA & $8.53 \mathrm{e}-06$ & -0.320598 & -0.201497 & -0.272847 \\
\hline 1 & 328.2204 & 583.8683 & $5.30 \mathrm{e}-09$ & -7.705509 & $-7.110002^{*}$ & -7.466753 \\
\hline 2 & 349.7059 & 38.13683 & $4.63 \mathrm{e}-09$ & -7.842647 & -6.770735 & -7.412887 \\
\hline 3 & 389.5018 & 66.65819 & $2.57 \mathrm{e}-09$ & -8.437546 & -6.889228 & $-7.816781^{*}$ \\
\hline 4 & 406.1136 & 26.16349 & $2.57 \mathrm{e}-09$ & -8.452839 & -6.428116 & -7.641070 \\
\hline 5 & 426.2915 & $29.76240^{*}$ & $2.37 \mathrm{e}-09^{\star}$ & $-8.557286^{*}$ & -6.056158 & -7.554513 \\
\hline 6 & 433.7278 & 10.22502 & $3.05 \mathrm{e}-09$ & -8.343196 & -5.365663 & -7.149418 \\
\hline 7 & 442.3601 & 11.00612 & $3.86 \mathrm{e}-09$ & -8.159002 & -4.705064 & -6.774219 \\
\hline 8 & 456.5493 & 16.67232 & $4.34 \mathrm{e}-09$ & -8.113732 & -4.183388 & -6.537945 \\
\hline t-statistic at 5\% significance level each, * Indicates the lag order selected by the criterion \\
LR- sequencial modified LR, FPE- Final prediction error, AIC- Akaike information criterion \\
SC- Schwarz information criterion, HQ- Hannan-Quinn information criterion \\
\hline
\end{tabular}

The selection of the appropriate lag length to use is shown in Table 3. Different lag order selection criteria are displayed and observed. The usual selection criteria weigh off the inefficiency instigated by over-parameterisation and the bias linked to thrifty parameterisation. The differing criteria provide a spectrum of the bias versus efficiency balance, thus showing differing results on lag order (Thorntorn and Batten, 1985). In Table 3, the FPE, AIC and HQ select 5 lag lengths. The lag selection is in this model based on majority. All the selection criteria used have their strengths and weaknesses based on their prejudice in the bias versus efficiency trade-off.

After concluding the lag order test, the Johansen procedure introduced tests for the existence of long run association among the variables in question. Two tests are available for this procedure namely the unrestricted cointegration rank test (Trace test) and the unrestricted cointegration test (Maximum Eigenvalue test). The relative strength and reliability of these two tests is however a subject of debate.

Table 4 (i): Trace tests

\begin{tabular}{|c|c|c|c|c|}
\hline $\begin{array}{c}\text { Hypothesised } \\
\text { No of CE(s) }\end{array}$ & Eigenvalue & $\begin{array}{c}\text { Trace } \\
\text { Statistic }\end{array}$ & $\begin{array}{c}0.05 \\
\text { Critical Value }\end{array}$ & Prob.** \\
\hline None * & 0.310016 & 48.07687 & 47.85613 & 0.0477 \\
\hline At most 1 & 0.112421 & 16.53453 & 29.79707 & 0.6742 \\
\hline At most 2 & 0.067297 & 6.397598 & 15.49471 & 0.6485 \\
\hline At most 3 & 0.005582 & 0.475803 & 3.841466 & 0.4903 \\
\hline $\begin{array}{l}\text { Trace test indicates 1 cointegrating eqn(s) at the } 0.05 \text { level } \\
\text { * denotes rejection of the hypothesis at the 0.05 level } \\
\text { **MacKinnon-Haug-Michelis (1999) p-values }\end{array}$ \\
\hline \multicolumn{5}{|l}{} \\
\hline
\end{tabular}

The cointegration tests are run with the 5 lags selected by the criteria assuming the existence of an intercept and no trend in the cointegration equation(s) and VAR, thus a linear deterministic trend. The null hypothesis of no cointegration will be rejected when the $p$-value is more than 0.05 . It is also rejected when the Trace and the Max-Eigen statistics are larger than the 0.05 critical values. For the Trace test the null hypothesis of no cointegration is rejected since the 0.0477 probability value is less than 5 per cent. The 48.07687 trace statistic is also larger than the 0.05 critical values of 47.85613. The trace test therefore suggests that one cointegration equation exists among the variables.

Table 4 (ii): Maximum Eigenvalue tests

\begin{tabular}{|c|c|c|c|c|}
\hline $\begin{array}{l}\text { Hypothesised } \\
\text { № of CE(s) }\end{array}$ & Eigenvalue & $\begin{array}{c}\text { Max-Eigen } \\
\text { Statistic }\end{array}$ & $\begin{array}{c}0.05 \\
\text { Critical Value }\end{array}$ & Prob.** \\
\hline None * & 0.310016 & 31.54234 & 27.58434 & 0.0147 \\
\hline At most 1 & & & & .7317 \\
\hline At most 2 & 7 & & 14.26460 & 0.6233 \\
\hline At most 3 & 0.005582 & 0.475803 & 3.841466 & 0.4903 \\
\hline \multicolumn{5}{|c|}{$\begin{array}{l}\text { Max-eigenvalue test indicates } 1 \text { cointegrating eqn(s) at the } 0.05 \text { level } \\
\text { * denotes rejection of the hypothesis at the } 0.05 \text { level } \\
* \text { MacKinnon-Haug-Michelis (1999) p-values }\end{array}$} \\
\hline
\end{tabular}


Likewise, the Maximum Eigenvalue test has a null hypothesis of no cointegration equation(s). The null hypothesis is rejected because the Maximum-Eigen statistic (31.54234) in Table 4 (ii) is greater than the critical value (27.58434) at $5 \%$ significance level. This decision is supported by the $p$-value $(0.0147)$ which is less than 0.05 . We conclude therefore that there is a long run association among the variables. The test indicates that one cointegration equation exists. It can be concluded from the concurrence between the above tests that there does exist a cointegration among the variables. With this understanding, it becomes clear that the relationships among the variables in question differ between the short run and long run periods. These variations in impulse can be accounted for using the vector error correction model.

The error correction model makes it possible to differentiate the impacts of the variables on the demand for labour into the short run and long run impacts. The results for the two periods are presented in the tables below.

Table 5: Long run cointegration results

\begin{tabular}{|c|c|c|c|}
\hline Variable & Coefficient & Standard error & t-statistic \\
\hline Constant & -42.4824 & & \\
\hline LnL & 1.000000 & & \\
\hline LnIMP (-1) & -0.11877 & $(0.04990)$ & {$[2.38016]$} \\
\hline LnOUT $(-1)$ & 0.022809 & $(0.00456)$ & {$[5.001974]$} \\
\hline LnWIR $(-1)$ & -0.08302 & $(0.03850)$ & {$[-2.156364]$} \\
\hline
\end{tabular}

The results obtained above make it possible to estimate the long run impacts of the variables on the demand for labour by substituting into the model as:

$$
L_{t}=-42.4824-0.0119 I M P+0.0228 O U T-0.083 W I R \text {. }
$$

From the results obtained, it is clear that all the variables are statistically significant. Import of textiles, manufacturing output and wage to interest ratio are the statistically significant variables as displayed by their absolute tstatistic values that are greater than 2 . The results obtained confirm the long run relations between the variables. The equation above can be interpreted as portraying the inverse long run impacts of imports and wage to interest ratio on the dependent variable workers demanded. It also shows that a positive long run relationship exist between workers demanded and manufacturing output. The relationship between demand for labour and imports of textiles can be inferred that a $1 \%$ increase in imports of textiles causes $0.118 \%$ decline in the demand for labour. The results also show that a $1 \%$ increase in manufacturing output result in $0.022 \%$ increase in the demand for workers. Similar increases in the ratio between wages and interest rate will result in $0.083 \%$ reduction in employment. The results obtained were compatible with the underlying economic theories.

Table 6: Error correction results

\begin{tabular}{|c|c|c|c|}
\hline Variable & Coefficient & Standard error & t-statistic \\
\hline DLnL(-1) & -0.079917 & 0.03348 & -2.38673 \\
\hline DLnIMP $(-1)$ & -0.111432 & 0.04863 & 2.29156 \\
\hline DLnOUT(-1) & 0.011242 & 0.01991 & 0.56457 \\
\hline DLnWIR (-1) & -0.034937 & 0.02089 & -1.67218 \\
\hline
\end{tabular}

Table 6 displays the error correction results obtained from the estimation procedure. The error correction results in the VECM approach show the rate at which the departures from equilibrium of the dependent variable are eliminated. The variations from the equilibrium condition may be caused by a large number of variables (some included and other omitted in the VAR). From the results obtained the rate of adjustment to equilibrium is about 8 per cent per quarter. This is shown by the coefficient -0.079917 which is statistically significant at -2.38673 . This means that only about 8 per cent adjustment back to equilibrium in the employment level. There is obviously limited pressure to rectify the disturbance. Empirically, these findings may be so because of the non-inclusion of other variables that may influence employment or the demand for workers.

Diagnostic checks make it possible to examine the econometric validity of a model (Brooks, 2008). The diagnostic tests include the Durbin-Watson (DW) test, White's test and the Jarque-Bera (JB) test. They test for serial correlation, heteroscedasticity and normality in the residuals respectively. The underlying concept in autocorrelation is that the error term in one period is positively correlated with the error term from the previous period. 
Table 7 (i): Durbin-Watson Serial Correlation tests results

\begin{tabular}{|l|l|l|}
\hline Method & Null Hypotheses & d-statistic \\
\hline Durbin-Watson (DW) & serial correlation exists at 5\% s.l & 0.435874 \\
\hline
\end{tabular}

The empirical validity of the model used in the study is assessed and displayed in Tables 7 (i) and 7 (ii). The tables show the findings of the Durbin-Watson, White's and Jarque-Bera tests for serial correlation, heteroscedasticity and normal distribution in the residual respectively. The null hypothesis in the DW test is the existence of serial correlation. At a selected level of significance, if the ( $d_{\text {calc }}$ ) is smaller than the tabulated value of lower limit $\left(d_{L}\right)$, the hypothesis of existence of serial correlation is accepted. The d-statistic of 0.436 is greater than 0.05 . The null hypothesis which states the existence of serial correlation will therefore be rejected.

Table 7 (ii): White and Jarque-Bera tests results

\begin{tabular}{|l|l|l|l|}
\hline Method & Null Hypotheses & t-statistic & p-value \\
\hline White's Test (No cross terms) & No conditional heteroscedasticity & 394.7435 & 0.8069 \\
\hline Jarque-Bera (JB) & Normal distribution & 0.708021 & 0.7019 \\
\hline
\end{tabular}

The White test for heteroscedasticity has the null hypothesis of no heteroscedasticity or that the residuals are homoscedastic. The null hypothesis is not rejected since the $p$-value of 0.807 is considerably higher than 0.05 . The null hypothesis would have been rejected had the p-value been less than the 5 per cent significance level in the test. To show whether there is normal distribution in the error terms, the JB test is used. The null hypothesis is the existence of normal distribution. The null hypothesis would be rejected if the p-value in the test is less than the 0.05 significance level. The findings of the diagnostic tests can jointly be concluded to ascertain that the model is a stable one whose results can at least be relied upon.

Analysis of the findings of the VAR will suggest which variables in the models are significantly related. The results will not however, by design, be capable of explaining the relationships or the duration required for the effects in the relationships to occur. The findings of the VAR alone are incapable of showing whether changes in variables will have inverse or positive impacts on the other variables or how long these effects will take in the process. Impulse response and variance decomposition analyses were therefore carried out. The impulse responses are illustrated in the Appendix.

The impulse response analysis provides a picture on the reaction of the dependent variable to shocks in the explanatory variables and itself. In this case the analysis focuses on the $L n L$ variable. The innovations in the variables in the system and their impulses are indicated in over 12 quarters or a 3 year period. A single period shock to LnIMP declines $L n L$ by less than a percentage point in the preceding periods. The effects of the shock though, persist and level of temporarily in the fourth period. Secondly, a one-period standard deviation shock to $L n O U T$ increases $L n L$ by about 4 per cent until the fourth quarter, where the impact dies off. Likewise, a single period shock to $L n W I R$ reduces $L n L$ by about 2 per cent but the impulse dies off after about 3 quarters. The shocks though do not follow a smooth pattern.

Variance decomposition analysis is a slightly different approach to the impulse response analysis in testing the effects of shocks in variables in the autoregressive system. The variance decomposition analysis will illustrate the fraction of changes in the labour demand caused by internal shocks in it, versus shocks to the other explanatory variables (LnIMP, LnOUT and LnWIR). The shock in $L n L$ is expected to have a direct effect on the variable itself. This shock is also transferred to the other variables through the dynamics of VAR system (Brooks 2002). It is anticipated that $L n L$ innovations will account for the majority of the error variance of the series.

Table 8: Variance Decompositions

\begin{tabular}{|c|c|c|c|c|c|}
\hline Period & S.E. & LL & LIMP & LOUT & LWIR \\
\hline 1 & 0.077674 & 100.0000 & 0.000000 & 0.000000 & 0.000000 \\
\hline 2 & 0.101695 & 98.27511 & 0.001899 & 1.450284 & 0.272710 \\
\hline 3 & 0.118726 & 89.87231 & 0.021940 & 6.485038 & 3.620713 \\
\hline 4 & 0.128647 & 80.98301 & 0.144433 & 14.64055 & 4.232007 \\
\hline 5 & 0.137785 & 75.01542 & 0.289215 & 19.04951 & 5.645860 \\
\hline 6 & 0.145831 & 71.47223 & 0.684390 & 20.18010 & 7.663279 \\
\hline 7 & 0.154614 & 65.92991 & 2.373126 & 20.23766 & 11.45930 \\
\hline 8 & 0.159912 & 62.91232 & 4.580093 & 20.19023 & 12.31736 \\
\hline \multicolumn{7}{|c}{} \\
\hline \multicolumn{7}{|c|}{234} \\
\hline
\end{tabular}




\begin{tabular}{|c|c|c|c|c|c|}
\hline 9 & 0.163270 & 60.91917 & 6.574064 & 20.00702 & 12.49974 \\
\hline 10 & 0.166192 & 59.23792 & 8.786501 & 19.36400 & 12.61157 \\
\hline 11 & 0.170376 & 56.58784 & 12.04188 & 18.42546 & 12.94481 \\
\hline 12 & 0.174536 & 54.19533 & 15.65671 & 17.76024 & 12.38772 \\
\hline \multicolumn{6}{|c|}{ Cholesky Ordering: LL LIMP LOUT LWIR } \\
\hline
\end{tabular}

Table 8 shows the variance decompositions for 12 periods, thus the extent to which the variances in the dependent variable are explained by shocks in the independent variables over time. The variance in labour demand in the first quarter is explained entirely by shocks in labour demand itself. Midway through the periods, variances in labour demand are explained about $71 \%$ by itself while the rest are explained by the independent variables with LIMP, LOUT and LWIR responsible for $0.8 \%, 20 \%$ and $8 \%$ respectively. After the 12 quarter period labour demand explains about 54 percent of its own variations. The impact caused by shocks in LIMP rises considerably to about $16 \%$ while LOUT falls to about $18 \%$ and LWIR rises to $12 \%$. By this period, the shocks in the explanatory variables account for almost proportionate variations in labour demand.

\section{Conclusions and Policy Recommendations}

The study focused on the major determinants of labour demand in the TCF manufacturing sector in South Africa which were industry output, wages and imports of TCF products. The study showed that significantly negative relationships exist between labour demand and wages and imports. These were considered as the major driving forces in the performance of the sector.

Despite various fiscal policy tools being implemented at a macro level, the study suggested various policies that could be implemented to remedy employment problems specific to the TCF sector. Wage and labour relations issues remain significant hindrances in the South African labour market. The Government should therefore implement a wage subsidy targeted specifically at reducing the costs of production that have helped cripple the TCF sector. The wage subsidy will have the impact of increasing the employers' propensity towards labour as the leading production factor. This would lead to greater assimilation of labour thereby reducing unemployment. Secondarily, wage disputes have been common phenomena of the labour market. The growth of unionism through Congress of South African Trade Unions (COSATU), Southern African Clothing and Textile Workers Union (SACTWU) and Southern African Footwear Leather Industries Association (SAFLIA) have increased the employees' ability to bargain thereby limiting employers' ability to manipulate labour and associated costs. Typical of these disputes, is the long duration with which they persist. The Government should act as a strong arbitrator who assists in reducing the disparities between employers and employees.

\section{References}

Alessandirini, M., (2009) "Jobless growth in Indian manufacturing: A Kaldorian Approach" University of Roma Department of Economics. 99. Roma Italy.

Barker, F., (2007) "The South African Labour Market: Theory and Practice." Van Schaik

Behar, A., (2004) "Estimates of labour demand elasticities and elasticities of substitution using firm level manufacturing data." CSSR Working Paper. 98. University of Cape Town.

Berman, E., Bound, J. and Griliches, Z., (1994) "Change in the demand for skilled labour within US manufacturing: Evidence from the Annual Survey of Manufacturers*." The Quarterly Journal of Economics, 109(2): 367-397.

Bhorat, H., (2003) "The Post Apartheid Challenge: Labour Demand Trends in the South African labour market, 1995-1999." Development Policy Research Unit. University of Cape Town.

Bhorat, H., and Jacobs, E., (2010) "An overview of the demand for skills for inclusive growth path." Development Bank of Southern Africa.

Brooks, C., (2002) "Introductory Econometrics for Finance." Cambridge University Press.

Brooks, C., (2008) "Introductory Econometrics for Finance."Cambridge University Press.

DA (The Democratic Alliance)., (2009) "Textile Sector Crisis- The DA's 8-Step solution." [Online]. Available: http://www.da.org.za/docs/591/textilesectorcrisis_document.pdf [Accessed 12 April 2012].

DTI (Department of Trade and Industry)., (2011). "Policy Statement: The South African Government's approach to future International Investment Treaties."

Ehrenberg, R.G. and Smith, R.S., (2006) "Modern Labour Economics: Theory and Public policy."Pearson Addison Wesley. Pearson Education Inc.

Freeman, R.B., and Medoff, J.L., (1982) "Substitution between Production labour and other Inputs in unionised and non-unionised manufacturing." Review of Economics and Statistics. 64(2): 220-233. MIT.

Gujarati, D.N and Porter, D.C., (2010)“Essentials of Econometrics."McGraw- Hill International Edition. 
Hamermesh, D.S., (1993) "Labour Demand."Princeton University Press: Princeton New Jersey.

Heshmati, A. and Ncube, M., (2003) "An econometric model of employment in Zimbabwe's manufacturing industries*." World Institute of Development Economics Research. SSE/EFI Working Paper series in Economics and Finance, 277.

IMF., (2009) "South Africa: 2009 article iv consultation."09(273). International Monetary Fund Washington: IMF.

Jauch, H. and Traub-Merz, R., (2006)"The Future of the Textile and Clothing Industry in Sub-Saharan Africa."Bonn: Friedrich-EbertStiftung: 2006.

Lewis, H. G., (1963) "Unionism and Relative Wages in the United States." Chicago University Press: Chicago

Lutkepohl, H., (1990). "Asymptotic Distributions of Impulse Response Functions and Forecast Error Variance Decomposiyions of Vector Autoregressive Models." The Review of Economics and Statistics. 72 (1). 116-125. MIT.

McConnell, C. R., Brue, S. L., and MacPherson, D. A., (2009) "Contemporary Labour Economics." McGraw Hill.

Moolman, E., (2003) "An Econometric Analysis of Labour Demand at an Industry Level in South Africa." Trade and Industrial Policy strategies. 5 .

Onaran, O., (2008) "The effect of import penetration on labour market outcomes in Austrian manufacturing industry. *" Vienna University of Economics and Business Administration.Department of Economics. 119: Vienna.

Roberts, M.J., and Skoufias, E., (1997 )"The long run demand for skilled and unskilled labour in Colombia manufacturing plants."The Review of Economics and Statistics. 79(2): 330-334.

Roberts, S., and Thoburn, J., (2004). "Globalisation and the South African textiles industry: Impacts on firms and workers." Journal of International Development. 16.

Salvatore, D., and Reagle, D., (2002) "Theory and Problems of Statistics and Econometrics." Schaums Outline Series. McGraw-Hill. (2): 228-235.

SEDA (Small Enterprise Development Agency)., (2008)"Survey on the Textile, Clothing and Footwear Sector: Focus on Small Enterprises." [Online]. Available: http://www.seda.org.za/Publications/Publications/Survey\%20on\%20the\%20textile,\%20clothing \%20and\%20Footwear\%20Sector.pdf [Accessed 24 April 2012].

StatsSA., (2009) "Labour Force Survey Historical revision: September series 2000-2007." Statistics South Africa. Statistical Release P0210.

StatsSA., (2011) "Quarterly Labour Force Survey: Quarter 4, 2010." Statistics South Africa Statistical Release P0211.

Teal, F., (1995) "Real Wages and the Demand for Labour in Ghana's manufacturing sector." Centre for the study of African economies: University of Oxford. 95(7).

Thorntorn, D. L., and Batten, D. S., (1985). "Lag-Length Selection and Tests of Granger Causality between Money and Income." Journal of Money, Credit and Banking. 17 (2) 164-178.

\section{Appendices}

Appendix: Impulse response of labour demand

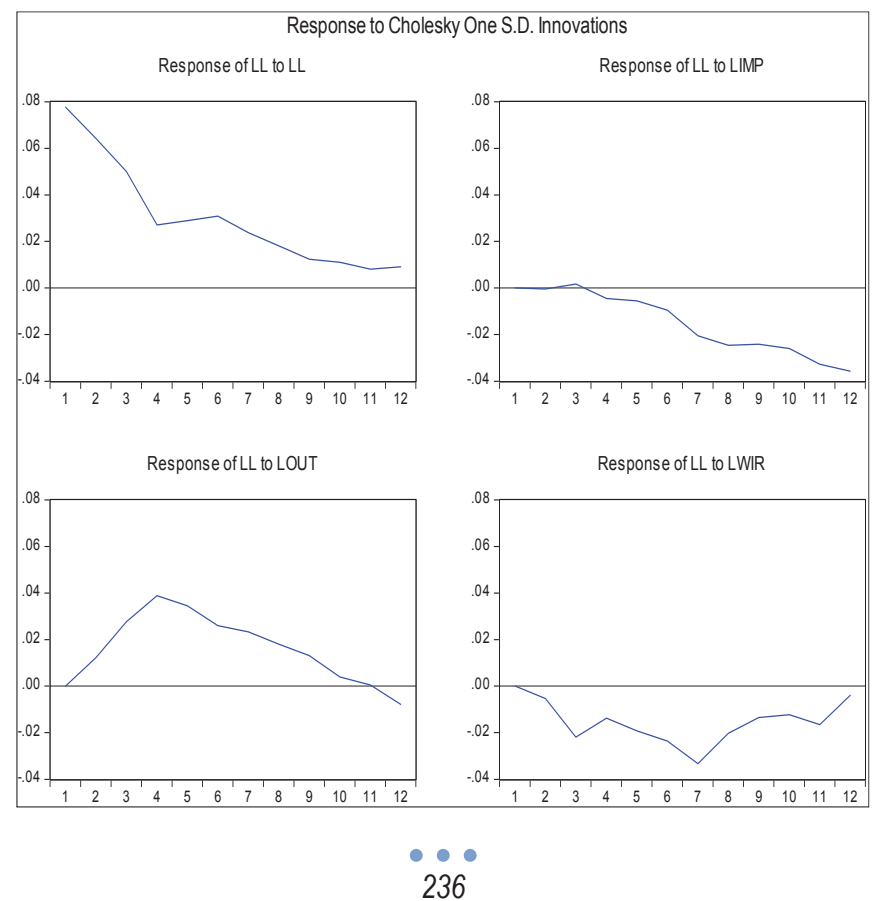

